UDC 541.18.02; 546.57

M.I. Skiba ${ }^{1}, \mathrm{PhD}$,

A.A. Pivovarov ${ }^{1}$, DSc, Prof.,

A.K. Makarova ${ }^{1}$,

V.I. Vorobyova ${ }^{2}, \mathrm{PhD}$,

I.A. Vasylenko ${ }^{1}$, $\mathrm{PhD}$, Assoc. Prof.,

A.A. Pasenko ${ }^{2}, \mathrm{PhD}$, Assoc. Prof.,

${ }^{1}$ Ukrainian State University of Chemical Technolodgy, 8 Gagarin Ave., Dnipro, Ukraine, 49005; e-mail: anmak123@mail.ru

${ }^{2}$ National Technical University of Ukraine “Igor Sikorsky Kyiv Polytechnic Institute”, 37 Peremohy Ave., Kyiv, Ukraine, 03056

\title{
OBTAINING SOLUTIONS OF SILVER NANOPARTICLES UNDER PLASMA DISCHARGE
}

\begin{abstract}
M.I. Скиба, О.А. Півоваров, А.К. Макарова, В.І. Воробйова, І.А. Василенко, О.О. Пасенко. Отримання розчинів наночасток срібла під дією плазмового розряду. Розглянуто одержання водних розчинів наночасток срібла із застосуванням розряду контактної нерівноважної низькотемпературної плазми. Метою роботи є дослідження впливу сили струму розряду контактної нерівноважної низькотемпературної плазми на склад розчинів наночасток срібла. Дослідження проводили в газорідинному реакторі періодичної дії об’ємом 100 мл. Тиск в реакторі становив $80 \pm 4$ кПа. Силу струму підтримували на рівні $120 \pm 6$ мА. Час плазмової обробки розчинів варіювали в діапазоні від $10 \mathrm{c}$ до 14 хв. Розчини готували шляхом розчинення нітрату аргентуму у дистильованій воді в заданому співвідношенні. Окислювально-відновний потенціал вимірювали через 30 с після припинення обробки розчинів КНП за допомогою іономіру И-160МИ. Спектри колоїдних розчинів отримували на спектрофотометрі UV-5800РС з використанням кварцових кювет в діапазоні довжин хвиль $190 \ldots 700$ нм. Мікрофотографії наночасток отримували на растровому електронному мікроскопі РЭМ-106И зі збільшенням у $100 . .2000$ разів. Додатковий аналіз розміру часток проводили методом динамічного світлорозсіювання на приладі VASCO (довжина хвилі лазеру - 658нм). Встановлено, що сила струму в ланцюзі, в процесі плазмового впливу на розчини нітрату срібла $є$ фактором, що впливає на вихід окиснених сполук та цільового продукту. Досліджено закономірності зміни окисно-відновного потенціалу водних розчинів нітрату аргентуму від концентрації $\mathrm{AgNO}_{3}$, тривалості дії плазмохімічного розряду та сили струму. Досліджено морфологічні та розмірні параметри плазмохімічно одержаних наночасток срібла. Встановлено, що в результаті дії розряду плазми утворюється дисперсна фаза наночасток переважно сферичної форми зрозміром до 50 нм.Збільшення сили стуму сприяє одержанню часток з більшим середнім розміром.

Ключові слова: розчин наночасток срібла, плазмовий розряд, сила струму
\end{abstract}

M.I. Skiba, A.A. Pivovarov, A.K. Makarova, V.I. Vorobyova, I.A. Vasylenko, A.A. Pasenko. Obtaining solutions of silver nanoparticles under plasma discharge. The paper considers obtaining water solutions of silver nanoparticles with contact non-equilibrium low temperature plasma discharge. The aim of the work is to study the influence current of a discharge non-equilibrium low-temperature plasma on the composition of silver nanoparticles solutions. The investigations were carried out in a gas-liquid batch reactor the volume of which 100 $\mathrm{ml}$. The reactor pressure was $80 \pm 4 \mathrm{kPa}$. The current was maintained at $120 \pm 6 \mathrm{~mA}$. The time of treatment was from 10 seconds till 14 minutes. The solutions were prepared by dissolving the argentums nitrate in distilled water with a predetermined ratio. Oxidation-reduction potential was measurement 30 seconds after stopping the treatment of solutions of CNP using an ionometr I-160MI. Optical spectra of sols were recorded on the spectrophotometer UV-5800PC in the wavelength range $190 \ldots 700 \mathrm{~nm}$. Micrographs of nanoparticles were obtained with a scanning electron microscope REM-106I with magnification of $100 \ldots 2000$ times. Additional particle size analysis was performed by dynamic light scattering on a VASCO instrument (laser wavelength $658 \mathrm{~nm}$ ). It is found, the current strength in the circuit is influence to the yield of oxidized compounds and the desired product. The regularities of the change in the oxidation-reduction potential of aqueous solutions of argentum nitrate are studied depending on the concentration of $\mathrm{AgNO}_{3}$, the time of action plasma discharge and amperage. Morphological and dimensional characteristics of plasmochemical obtaining silver nanoparticles were researched. It is found the dispersion phase of nanoparticles witch produced in results action of plasma discharge has size up to $50 \mathrm{~nm}$ and spherical form. If the amperage is growing it will produce the bigger particles.

Keywords: solution of silver nanoparticles, plasma discharge, amperage

\section{Introduction}

The specific properties of metals in the ultrafine and nanosized state provide great opportunities for the creation of new effective materials and their use in various industries.

Of particular interest are nanoparticles of silver and concentrated aqueous dispersions on their basis. The combination of physico-chemical and antibacterial properties makes them promising for use in water purification and water treatment technologies, chemical industry, biotechnologies, medicine and others.

\section{$\overline{\text { DOI }}$}

(C) 2017 The Authors. This is an open access article under the CC BY license (http://creativecommons.org/licenses/by/4.0/). 
Thus, there information on the efficiency of the introduction of nanosized silver particles with increased chemical, biological, bactericidal and antimicrobial activity into a matrix of metal oxyhydroxide, polymer films of various composition for controlling pathogens, water treatment, and sewage is presented in papers [1 -3$]$.

The structure and properties of nanoparticles of metals are largely determined by the method of their obtaining. The most common way of obtaining nanoparticles of silver is to restore the silver salts using a wide range of reagents-reducing agents. However, the need for the use of reducing components sharply narrows the scope of their subsequent application use. Therefore, the development of new highly effective and innovative technologies aimed at obtaining nanosized particles of silver and concentrated aqueous dispersions on their basis is currently relevant.

Today, among the innovative methods of obtaining nanosized compounds, one of the most environmentally a friendly and energy-saving method is the use of plasma discharges [4].

Thus, in [5 - 8], authors report the possibility of obtaining nanoparticles of metals and their oxides directly by means of a plasma discharge generated between electrodes immersed in a liquid [5, 6], at the boundary of the phase separation of the "gas-liquid" under reduced pressure [7, 8] and others.

At present, plasma discharges are used mainly in the gas phase. For this purpose corona, barrier or spark plasma discharges are used. Contact nonequilibrium low-temperature plasma (CNP) is promising in terms of practical application among plasma-chemical discharges.

The plasma discharge is generated between the electrode that located in the gas phase and the liquid surface in the volume of which the second electrode is located. Thus, the chemical transformations at the boundary of the phase distribution are due to the complex influence of electrochemical oxidation-reduction; reactions of photolysis initiated, UV - irradiation; the flow of charged particles from the gas phase to the surface of the liquid medium $[9,10]$.

Variation of the composition of liquid phases makes it possible to control the routes of chemical transformation and the composition of obtained products. In [11], the authors show the effectiveness of the use of CNP for obtaining of nanosheets of silver from aqueous solutions of metal salts in a single technological step without the use of reagents-reducing agents.

Optimizing factors of plasma-chemical influence on the processed medium are: discharge current strength, reactor pressure, duration of plasma exposure, concentration of solutions, temperature and acidity of solutions. The study of the indicated parameters of plasma production of inorganic particles of silver has a scientific and practical interest.

The purpose of this work is to investigate the effect of the discharge current of a contact nonequilibrium low-temperature plasma on the composition of solutions of nanoparticles of silver.

Materials and methods. The research was carried out in a gas-liquid reactor of periodic action volume of $100 \mathrm{ml}$. Used electrodes made of stainless steel X18H10T. The cathode $(d=4 \mathrm{~mm})$ is located in the liquid part, and the anode $(d=2.4 \mathrm{~mm})$ - at a distance of $10 \mathrm{~mm}$ from the surface of the solution. The volume of the solution in the reactor was $70 \mathrm{ml}$. Continuous circulation of cold water provided of cooling of the reaction mixture.

The pressure in the reactor was $80 \pm 4 \mathrm{kPa}$. To obtain a plasma discharge to the electrodes, a voltage of $500 \ldots 1000 \mathrm{~V}$ was applied. The current strength was maintained at $120 \pm 6 \mathrm{~mA}$. The plasma processing time of the solutions varied from 10 seconds to 14 minutes. Solutions were prepared by dissolving the nitrate of the argentum in distilled water at a given ratio.

The oxidation-reduction potential (ORP) was measured 30 seconds after the treatment of the CNP solutions was stopped using the I-160MI ionomer using platinum and chloride electrodes. The spectra of colloidal solutions were obtained on a UV-5800PC spectrophotometer using a quartz cuvette in the wavelength range of $190 \ldots 700 \mathrm{~nm}$.

Microphotographs of nanoparticles were obtained on a raster electron microscope REM-106I with an increase of $100 . . .2000$ times. Using an electron microscope, images were obtained in the mode of operation in secondary electrons. The limiting residual pressure in the column microscope was no more than $6.7 \cdot 10^{-4} \mathrm{~Pa}$ at a current of $76 \mathrm{~mA}$ gun. An additional analysis of the particle size was carried out by the method of dynamic light scattering on the VASCO device (wavelength of laser - $658 \mathrm{~nm}$ ). 


\section{Results and discussion}

According to the Mi-Droude theory, the optical properties of colloidal solutions of nanoparticles of metals are characterized by the presence of a pronounced resonant absorption spectrum of the surface plasmon resonance (SPR) in the visible spectrum. The positions of the maximum SPP serve as a characteristic of both the form of the existence of colloidal silver in the aqueous medium and the size of the nanoparticles $[12,13]$. Scientists have reliably established that the maximum absorption of silver nanoparticles of spherical shape is characterized by the presence of a maximum absorption in the range $400 \ldots 440 \mathrm{~nm}$ [13]. The $\mathrm{Ag}^{0}$ atoms and $\mathrm{Ag}^{+}$ions in the solution serve as material for the further formation of nanoparticles.

It is believed that the formation of nanoparticles is preceded by a series of intermediate stages of the formation of stable small clusters, the "clumping" of which leads to the formation of quasimetallic and nanosized particles. In particular, the neutral atoms $\mathrm{Ag}^{0}$ and $\mathrm{Ag}^{+}$ions form such a "family" of "magic" clusters [14]:

$$
\begin{gathered}
\mathrm{Ag}^{+}+\mathrm{e}_{\mathrm{aq}}{ }^{-} \rightarrow \mathrm{Ag}^{0}\left(k=4.8 \cdot 10^{10} \mathrm{M}^{-1} \cdot \mathrm{s}^{-1}\right) ; \\
\mathrm{Ag}^{0}+\mathrm{Ag}^{+} \rightarrow \mathrm{Ag}_{2}{ }^{+}\left(k=8.5 \cdot 10^{9} \mathrm{M}^{-1} \cdot \mathrm{s}^{-1}\right) ; \\
\mathrm{Ag}^{2+}+\mathrm{Ag}^{+} \rightarrow \mathrm{Ag}_{3}{ }^{2+}\left(k=2.0 \cdot 10^{9} \mathrm{M}^{-1} \cdot \mathrm{s}^{-1}\right) ; \\
2 \mathrm{Ag}_{2}{ }^{+} \rightarrow \mathrm{Ag}_{4}{ }^{2+} ; \mathrm{Ag}_{4}{ }^{2+}+4 \mathrm{Ag}^{0} \rightarrow \mathrm{Ag}_{8}{ }^{2+}
\end{gathered}
$$

In order to determine the laws of the influence of the plasma discharge current on obtaining solutions of silver nanoparticles, samples of concentration in the range from $0.085 \ldots 0.5 \mathrm{~g} / \mathrm{l}$ were processed at different values of current strength in the chain, but at constant pressure in the reactor. According to experimental data, the optical densities of formed silver solutions of different concentrations, shown in Fig. 1, were constructed.

The analysis of the data shows that for all initial concentrations of solutions, an increase in the current strength of discharge from 120 to $220 \mathrm{~mA}$ helps to reduce the duration of the maintenance required for the formation of nanosheets of silver.

In addition, it was found that in all investigated solutions, the time interval of formation of stable small clusters, preceding the formation of nanosheets of silver, is much longer with a current of 120 $\mathrm{mA}$ and measured in minutes compared with an interval of 30 seconds. At a current of $220 \mathrm{~mA}$.

For the investigated solutions, when the current is applied with a force $I=120 \mathrm{~mA}$, the induction period for the formation of $\mathrm{Ag}_{4}{ }^{2+}$ clusters is due to the $\mathrm{Ag}^{2+}$ dimerization, during the action of the CNP, characterized by the presence of a SPR peak in the characteristic range of $260 \ldots 280 \mathrm{~nm}$.

In all cases, the formation of $\mathrm{Ag}_{4}{ }^{2+}$ clusters is observed after the first seconds of plasma discharge on the treated medium and remains until the formation of clusters of the $\mathrm{Ag}_{8}{ }^{2+}$ structure. The relative stability of the $\mathrm{Ag}_{4}{ }^{2+}$ cluster is due to the potential variable $E(n)$, which depends on the small values of $n$ in the equilibrium equation [12-14]:

$$
\begin{gathered}
\mathrm{Ag}_{n} \leftrightarrow \mathrm{Ag}_{n-1}+\mathrm{Ag}^{+}+e^{-} \\
\left(n=1, E^{\circ}=-1,8 \mathrm{~V} ; n \rightarrow \infty, E^{\circ}=0.799 \mathrm{~V}\right), \\
\mathrm{Ag}_{n}+n \mathrm{Ag}^{+} \leftrightarrow \mathrm{Ag}_{n+x} x^{++} .
\end{gathered}
$$

The increase in the duration of the treatment of the CNP solution leads to the stable formation of $\mathrm{Ag}_{8}{ }^{2+}$ clusters whose lifetimes are measured, in some cases, tens of minutes and is characterized by different data, the main absorption band in the range $270(290) \ldots 330 \mathrm{~nm}$. For further growth of the number of particles there are quasimetal centers, for which a wide absorption band with a maximum of $350 . .370 \mathrm{~nm}$ is characteristic. The final formation of nanoparticles at a current of $120 \mathrm{~mA}$ occurs from the second to the fourth minute of processing; At a current of $220 \mathrm{~mA}$, after $30 \ldots 40$ seconds, the peaks of SPR at $560 \mathrm{~nm}$ are shifted, which is evident in the formation of particles of a non-spherical shape.

For the concentration of silver nitrate in a solution of $0.12 \mathrm{~g} / \mathrm{l}$ at a current of $120 \mathrm{~mA}$, the formation of the nanoparticles is observed in the fourth ... sixth minute; at a current of $220 \mathrm{~mA}$ the greatest intensity of peaks is observed in $30 . . .40$ seconds. At the initial concentration (silver nitrate in solution), $0.2 \mathrm{~g} / \mathrm{l}$, the nanoparticles is fixed at the fourth ... sixth minute and $30 \ldots 40$ seconds at a current of 
120 and $220 \mathrm{~mA}$, respectively. At concentration of silver nitrate in a solution of $0,5 \mathrm{~g} / \mathrm{l}$ the time necessary for reception of nanoparticles of silver, makes 14 minutes and $8 \ldots 10$ minutes at a current of 120 and $220 \mathrm{~mA}$, respectively.
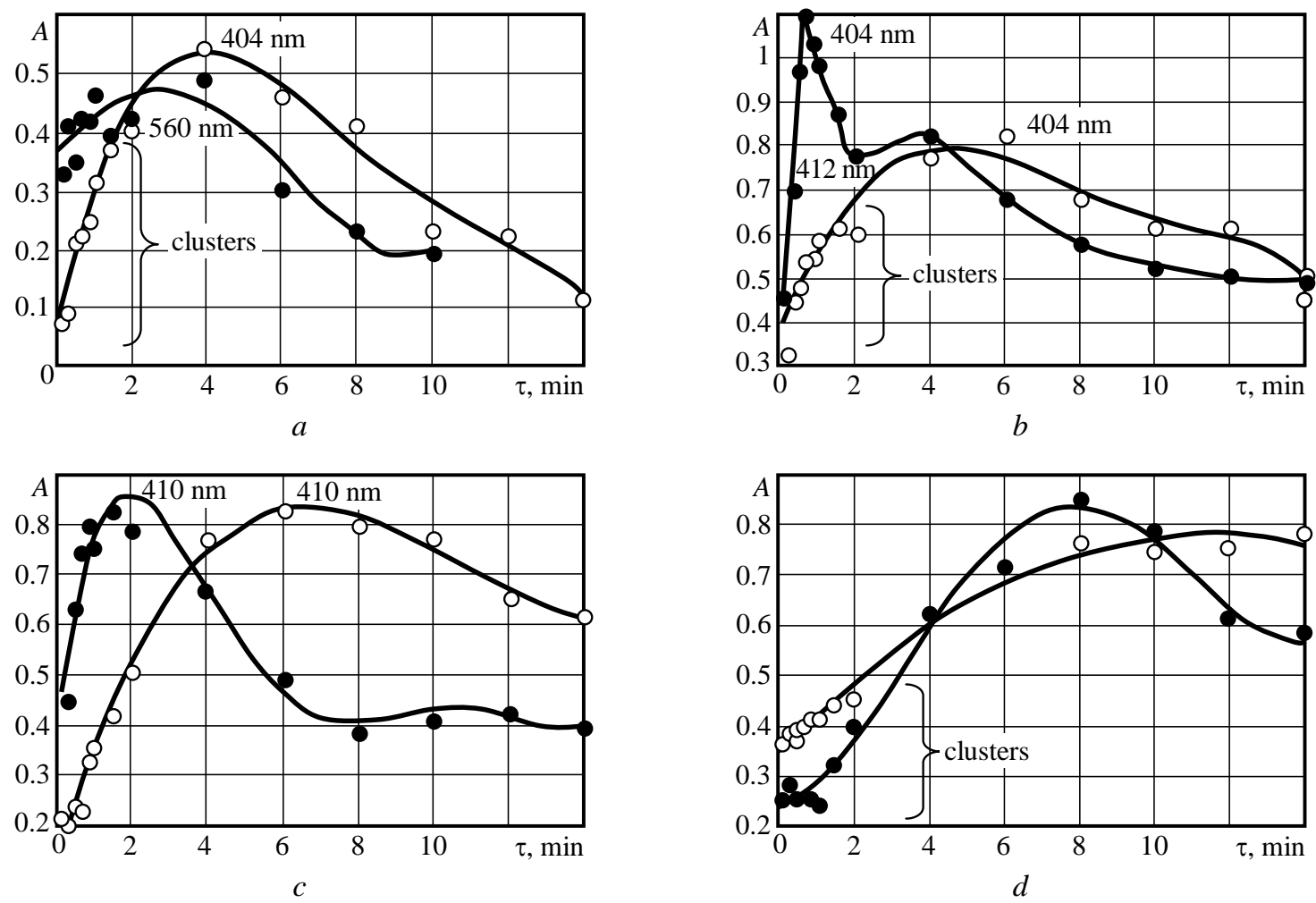

Fig. 1. The dependence of the optical density of the obtained solution of silver nano-particles on the current strength $(-220 \mathrm{~mA} ; \bigcirc-120 \mathrm{~mA})$ and the concentration of silver nitrate $\mathrm{C}, \mathrm{g} / \mathrm{l}: 0.085$ (a); 0,12 (b); 0.2 (c); 0,5 (d)

An important characteristic of the compounds formed in the aqueous medium during the treatment of CNP is the oxidation-reduction potential, which characterizes the content of oxidized and reduced forms of all redox pairs present in the solution. The nature of the dependence of the magnitude of the oxidation-reduction potential (ORP) on the time of treatment of solutions with low-temperature plasma is conveniently analyzed in the form of a graphical comparison of the values of ORP with the initial concentrations of solutions. The obtained results are presented in Fig. 2.

Implementation of plasmochemical treatment at a current of $120 \mathrm{~mA}$ for all studied time intervals of plasma influence on aqueous solutions of silver allows us to observe a logical change in ORP: initially, ORP is reduced to a certain "concentration limit", then sharply increases, but with further increase in the content of the precursor is almost unchanged.

The increase in the current strength of the processing changes the nature of the law: "concentration limit" is observed at higher values of the precursor in the solution, after which the value of ORP is sharply reduced.

Obviously, the yield of a product of the oxidation-reduction transformation of $\mathrm{H}_{2} \mathrm{O}$ and silver in both cases is determined by a combination of a significant number of factors (for example: plasmachemical outputs of their radical particles, redox potentials, concentrations, acidity of solutions, temperature) and therefore it is difficult to predict and requires additional research.

In processed CNP solutions of silver as the main reactive components should be considered relatively stable non-radical particles - products of oxidation and recovery of water molecules and the recovery of silver ions. 

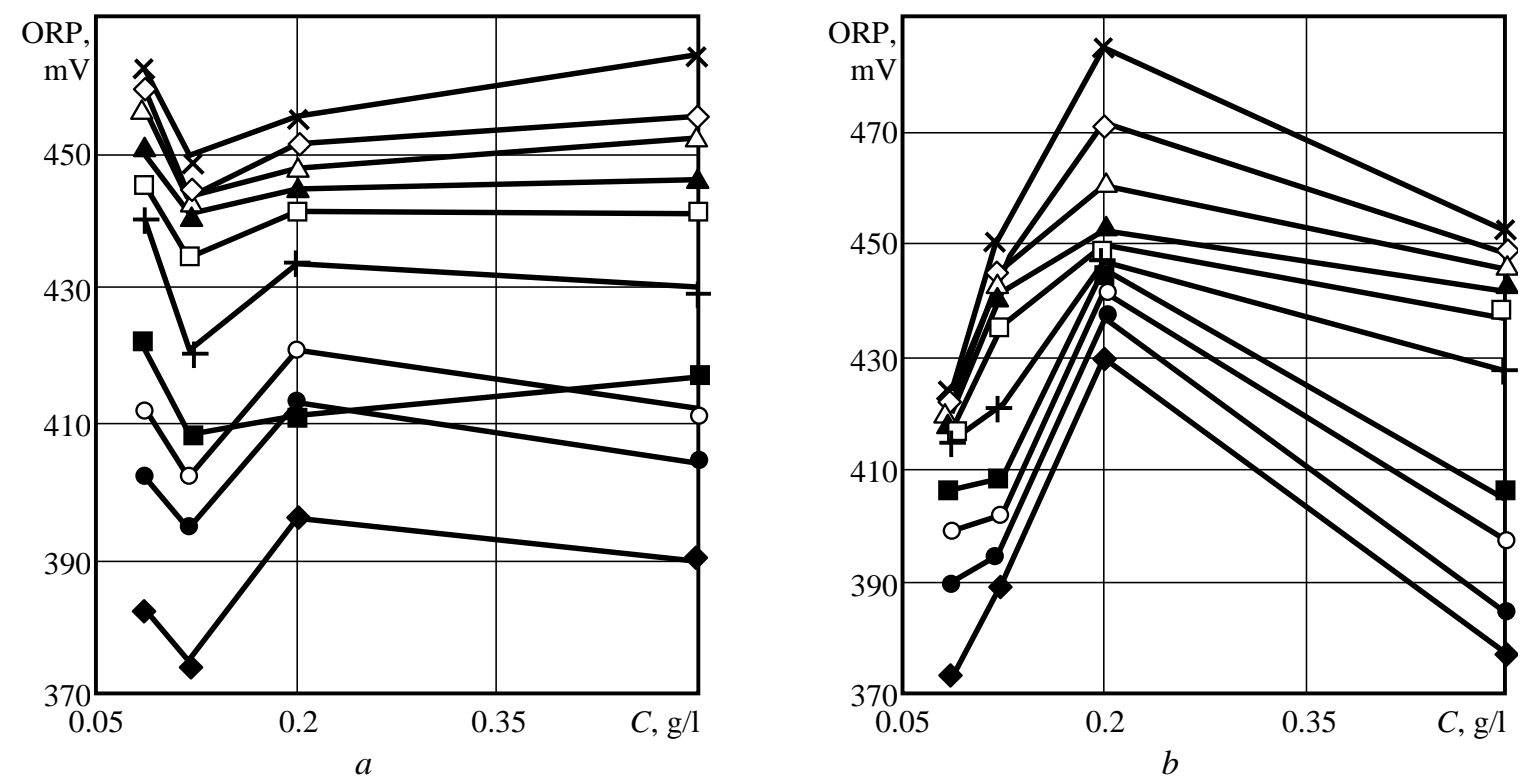

Fig. 2. The comparison of the oxidation-reduction potentials of the silver solution with the concentration of solutions depending on the duration of the plasma processing and the current strength: $I=120 \mathrm{~mA}(\mathrm{a}), I=220$ $m A(b) ; \bullet-1 ; 0-1.5 ; \boldsymbol{\square}-2 ; \boldsymbol{+}-4 ; \square-6 ; \boldsymbol{\Delta}-8 ; \Delta-10 ; \diamond-12 ; \mathbf{X}-14 ; \diamond-0.5 \min$

The set of data obtained gives grounds to consider that the current strength in the chain during the plasma influence on solutions for the formation of nanoparticles is a factor affecting the yield of oxidative agents, and, as a consequence, the target product.

The observed laws to be explained by the change in the size of the "cathode spot" formed by the plasma discharge torch on the surface of the solution in the plasma-chemical reactor. As is known, the surface of the phase separation "liquid-gas" in the plasmochemical reactor acts as a bipolar electrode, the outer part of which serves as a cathode, and the inner part of the surface layer of the liquid phase is an anode.

It is obvious that the intensity of plasmochemical processes should be determined by the area of the bipolar electrode, because in this zone of solution most of the chemical transformations that are caused by fluxes of charged particles of the plasma are realized. In the course of experiments on measuring the area of the "cathode spot" it was found that the variation of the current strength of the plasma discharge affects its size (Fig. 3).

It was also found that in addition to the current strength of the plasma discharge, the area of the "cathode spot" defines the distance from the anode to the surface of the solution. The obtained pattern can be explained by changing the rate of the process of generation of ionized particles in the gas phase. Obviously, the higher the number of electrons and molecules in the gas phase, the greater the number of effective collisions, which lead to ionization of particles and radiation in the visible range of the electromagnetic spectrum. As the number of electrons increases and at constant pressure in a plasma-chemical reactor (i.e., at a constant concentration of molecules), the rate of generation of ions will reach a certain limit value.

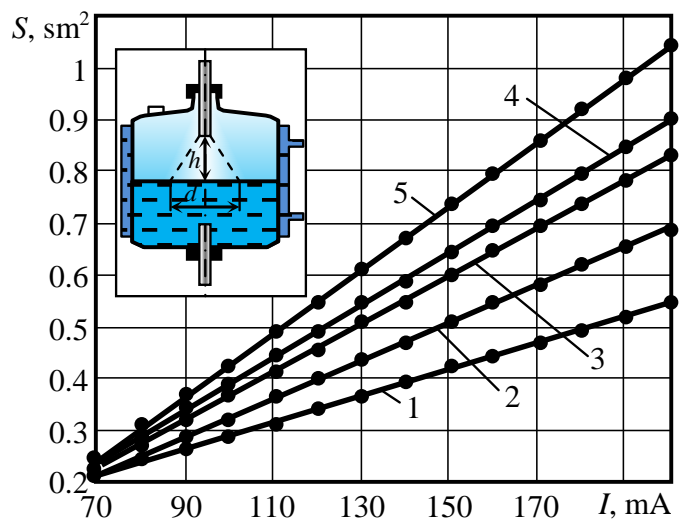

Fig. 3. The dependence of the area of the cathode spot on the current strength in the chain at the distance between the surface of the solution and the anode 3 (1), 5 (2), 7 (3), $8(4), 10(5) \mathrm{mm}$ 
Moreover, the smaller the distance between the electrodes, the less the number of gas phase molecules will be involved in the plasma discharge, and less number of ionized particles will dissipate as they move from the anode to the cathode. Increasing the efficiency of the process of obtaining nanosheets of silver is possible by increasing the current density in the chain and subject to the propagation of a plasma torch (ie, a cathode spot) on the entire surface of the solution in the reactor.

The above mentioned optical density data of silver nanoparticles obtained at different values of current strength indicate a slight difference in the formed nanoparticles, both in size and form. To characterize nanoparticles of silver synthesized using contact non-equilibrium plasma at different values of current strength, the samples were subjected to electron microscopic examination. The concentration of silver nitrate used in the study of aqueous solutions was $0.5 \mathrm{~g} / \mathrm{l}$. The obtained results are shown in Fig. 4.

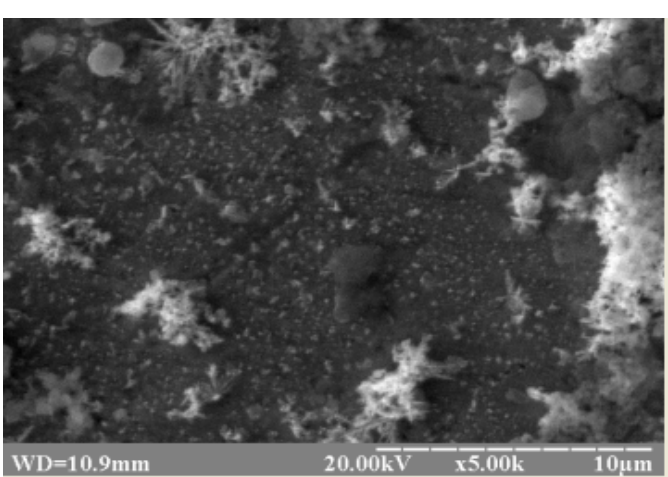

$a$

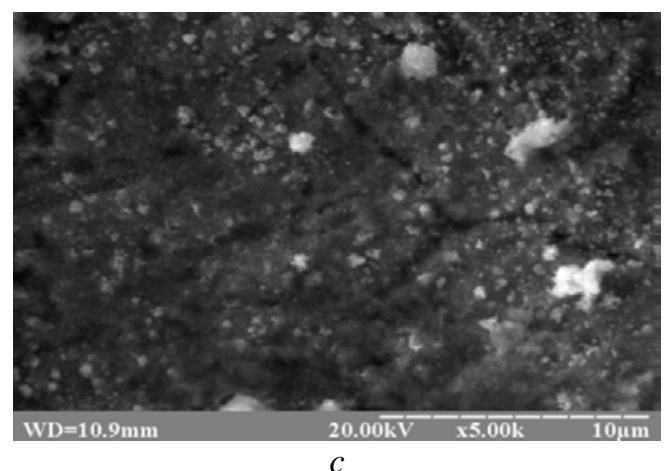

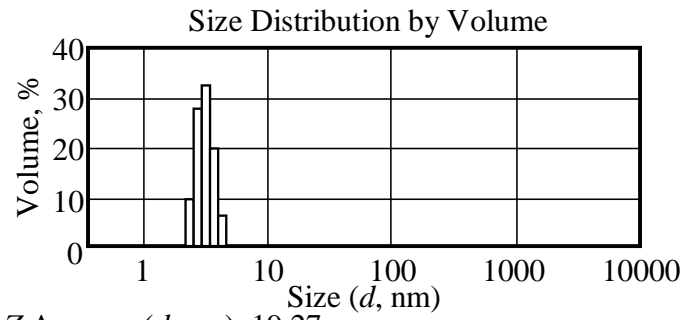

$Z$.Average $(d, \mathrm{~nm}): 19.27$

$b$

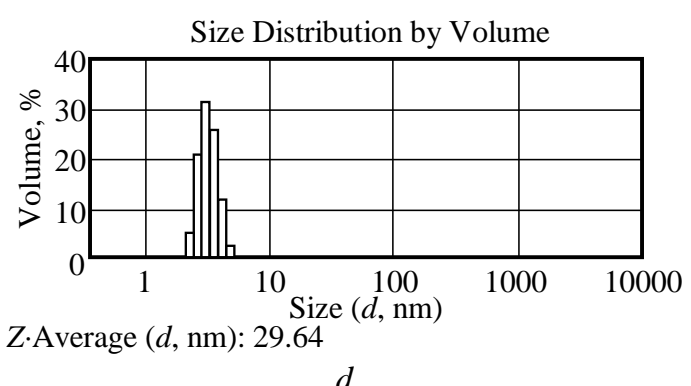

$d$

Fig. 4. Microphotographs (SEM) of silver particles $(a, c)$ and distribution of the received nanoparticles using the contact non-equilibrium low-temperature plasma at the current strength in the circuit $120 \mathrm{~mA}(a, b)$, $220 m A(c, d)$

According to electronic microscopy under the action of a plasma discharge at both values of the current strength, a dispersed phase of nanoparticles is formed. With values of a current of $120 \mathrm{~mA}$, the average size of the formed particles is $19.27 \mathrm{~nm}$. An increase in stomp strength of up to $220 \mathrm{~mA}$ helps to produce particles with a larger mean of $29.64 \mathrm{~nm}$.

\section{Conclusions}

The paper presents the results of the study of obtaining aqueous solutions of silver nanoparticles using a discharge of contact non-equilibrium low-temperature plasma. It was established that the current strength of the chain in the process of plasma influence on silver nitrate solutions is a factor affecting the output of oxide compounds and the target product. The regularities of the change in the oxidation-reduction potential of aqueous solutions of nitrate argentum from the concentration of silver nitrate, the duration of plasmochimic discharge and strength The effect of the plasma discharge current on the dimensional parameters of the particles obtained is investigated. It is established that as a result of the plasma discharge a dispersed phase of nanoparticles is formed mainly of a spherical shape with 
a diameter of $50 \mathrm{~nm}$. When the values of the current strength of $120 \mathrm{~mA}$, the average size of the formed particles is $19.27 \mathrm{~nm}$. An increase in the stomp strength of up to $220 \mathrm{~mA}$ helps to produce particles with a larger average size of $29.64 \mathrm{~nm}$.

\section{Література}

1. Amin, M.T. A review on removal of pollutants from water/wastewater using different types of nanomaterials / M.T. Amin, A.A. Alazba, U. Manzoor // Advances in Materials Science and Engineering. 2014. - Vol. 1. - 24 p. Article ID 825910.

2. Gehrke, I. Innovations in nanotechnology for water treatment / I. Gehrke, A. Geiser, A. SombornSchulz // Nanotechnology, Science and Applications. - 2015. - Vol. 8. - P. 1 - 17.

3. New inorganic (an)ion exchangers based on (alkoxide-free) sol-gel generated layered Mg-Al hydrous oxides for target anions (Arsenate, Arsenite, Fluoride, Bromide, Bromate, Selenite) removal / Natalia Chubar //Fifteenth International Water Technology Conference Alexandria, Egypt. - 2011. - P. 1 - 5.

4. Saito, Genki. Nanomaterial Synthesis Using Plasma Generation in Liquid / Genki Saito, Tomohiro Akiyama // Journal of Nanomaterials. - 2015. - 21 p. Article ID 123696.

5. Sun, B. Optical study of activespecies produced by a pulsed streamer corona discharge inwater / B. Sun, M. Sato, J.S. Clements // Journal of Electrostatics. - 1997. - Vol. 39, No. 3. - P. 189 - 202.

6. Bruggeman, P. Optical emission spectroscopy as a diagnostic for plasmas in liquids: opportunities and pitfalls / P. Bruggeman, T. Verreycken, M.A. Gonz'alez // Journal of PhysicsD: Applied Physics. 2010. - Vol. 43, No. 12. - 8 p. Article ID 124005.

7. Kaneko, T. Static gas-liquidinterfacial direct current discharge plasmas using ionic liquidcathode / T. Kaneko, K. Baba, R. Hatakeyama // Journal of Applied Physics. - 2009. - Vol. 105, No. 10, - P. 21. Article ID103306.

8. Jamroz, P. Development of directcurrent, atmospheric - pressure, glow discharges generated incontact with flowing electrolyte solutions for elemental analysisby optical emission spectrometry / P. Jamroz, K. Greda, P. Pohl // Elsevier. - 2013. - Vol. 108, - P. 74 - 82.

9. Півоваров, О.А. Використання контактної нерівноважної низькотемпературної плазми в гідрометалургійній промисловості: монографія / О.А. Півоваров, М.І. Скиба. - Дніпропетровськ: Акцент ПП, 2015. - $206 \mathrm{c}$.

10. Пивоваров, А.А. Неравновесная плазма: процессы активации воды и водных растворов: монография /. А.А.Пивоваров, А.П. Тищенко. — Днепропетровск: Грек, 2006. - 225 с.

11. Пасенко, О.О. Плазмохімічне одержання наночасток срібла / О.О. Пасенко, М.І. Скиба, А.К. Макарова, та ін. // Вопросы химии и химической технологии. - 2016. - № 4 (108). - С. 93 - 97.

12. Silver atoms and clusters in aqueous solution: absorption spectra and the particle growth in the absence of stabilizing $\mathrm{Ag}^{+}$ions / B.G. Ershov, E. Janata, A. Henglein, A. Fojtik // Journalof Physical Chemistry. 1993. - Vol. 97. - Iss. 18. - P. 4589 - 4594.

13. Baetzold, Roger C. Silver-Water Clusters: A Theoretical Description of $\mathrm{Ag}_{n}\left(\mathrm{H}_{2} \mathrm{O}\right)_{m}$ forn=1-4; $m=1-4$ / Roger C. Baetzold // Journal Physical Chemistry. - 2015. - Vol. 119. - Iss. 15. - P. 8299 - 8309.

14. Fluorescent silver oligomeric clusters and colloidal particles / M. Treguer, F. Rocco, Geraldelong, et al. // Solid State Sciences. - 2012. - Vol. 7. - Iss. 7. - P. 812 - 818.

\section{References}

1. Amin, M.T., Alazba, A.A., \& Manzoor, U. (2014). A review on removal of pollutants from water/wastewater using different types of nanomaterials. Advances in Materials Science and Engineering, 1, 24 p. Article ID 825910.

2. Gehrke, I., Geiser, A., \& Somborn-Schulz, A. (2015). Innovations in nanotechnology for water treatment. Nanotechnology, Science and Applications, 8. 1-17.

3. Chubar, N. (2011). New inorganic (an)ion exchangers based on (alkoxide-free) sol-gel generated layered Mg-Al hydrous oxides for target anions (Arsenate, Arsenite, Fluoride, Bromide, Bromate, Selenite) removal. Fifteenth International Water Technology Conference. (pp. 1-5) Egypt.

4. Genki Saito, \& Tomohiro Akiyama (2015). Nanomaterial Synthesis Using Plasma Generation in Liquid. Journal of Nanomaterials, 21 p. Article ID 123696.

5. Sun, B., Sato, M., \& Clements, J.S. (1997). Optical study of active species produced by a pulsed streamer corona discharge in water. Journal of Electrostatics, 39, 189-202. 
6. Bruggeman, P., Verreycken, T., \& Gonz'alez, M.A. (2010). Optical emission spectroscopy as a diagnostic for plasmas in liquids: opportunities and pitfalls. Journal of PhysicsD:Applied Physics, 43, 8. Article ID 124005.

7. Kaneko, T., Baba, K., \& Hatakeyama, R. (2009). Static gas-liquid interfacial direct current discharge plasmas using ionic liquid cathode. Journal of Applied Physics, 105(10), 21. Article ID 103306.

8. Jamroz, P., Greda, K., \& Pohl, P. (2013). Development of directcurrent, atmospheric-pressure, glow discharges generated in contact with flowing electrolyte solutions for elemental analysis by optical emission spectrometry. Elsevier, 108, 74-82.

9. Pivovarov, O.A., \& Skiba, M.I. (2015) Use the contact nonequilibrium low-temperature plasma in hydrometallurgical industry: monograph. Dnipro: Akcent. PP, 206 p.

10. Pivovarov, O.A., \& Tishenko, A.P. (2006). Nonequilibrium plasma: activation processes of water and aqueous solutions: monograph. Dnipro: Grek. 225 p.

11. Pasenko, O.O., Skiba, M.I., Makarova, A.K., Vorobjova, V.I., \&. Pivovarov, O. A. (2016). Obtain in gnanoparticles of silver plasmachemical method. Voprosy himii i himicheskoj tehnologii, 4, 93-97.

12. Ershov, B.G., Janata, E., Henglein, A., \& Fojtik, A. (1993). Silver atoms and clusters in aqueous solution: absorption spectra and the particle growth in the absence of stabilizing $\mathrm{Ag}^{+}$ions. Journal of Physical Chemistry, 97, 4589-4594.

13. Roger, C., \& Baetzold. (2015). Silver-Water Clusters: A Theoretical Description of $\operatorname{Ag}_{n}\left(\mathrm{H}_{2} \mathrm{O}\right)_{m}$ forn=1-4; m=1-4. Journal of Physical Chemistry, 119, 8299-8309.

14. Treguer, M., Rocco, F., Geraldelong, Anne Le Nestour, Cardinal, Th., Maali, A. \& Lounis, B. (2012). Fluorescent silver oligomeric clusters and colloidal particles. Solid State Sciences, 7, 812-818.

Received March 13, 2017

Accepted June 06, 2017 